\title{
THE HANDICAP PROFILE OF THE SPINAL CORD-DAMAGED IN CASE FILE, COMMUNICATION DOCUMENTS AND POPULATION SURVEY
}

\author{
By Margaret Agerholm, M.A., B.M., B.S. \\ Heenan House Rehabilitation and Resettlement Resource Centre for the Physically \\ Handicapped, Mare St., Hackney, London.
}

\begin{abstract}
Definitions" of handicap are given, with a classification of intrinsic (personal) handicaps, as well as Tables for the preparation of an individual's Handicap Profile, of use in population Surveys and in case files."
\end{abstract}

Key words: Classification; Handicap; Surveys; Questionnaire; Case records.

\section{Introduction}

ThIs paper is Part II of one which I gave to this Society in 1975, titled 'An Interdisciplinary Language for the Recognition and Evaluation of Handicap Arising from Spinal Cord Damage'. Part I presented, in the spinal cord context, the classification and nomenclature of Intrinsic (Personal) Handicap which had been published in a wider context, that of handicaps arising from all handicapping disorders, earlier in the year (Agerholm, 1975a, 1975b.)

Table I shows the definitions of handicap, and of its two broad divisions, extrinsic and intrinsic handicap, inside which the classification is based. Definitions are essential preliminaries to any classification. Here they enable us to distinguish handicap from non-handicap, and the enduring intrinsic handicaps from the escapable extrinsic handicaps of environment and circumstance.

Table II shows the classification of intrinsic handicaps, which are the more immediate concern of the clinician. There are nine 'Key' Handicaps, and 4I Components of handicap, each of the latter having its fixed place as a 'sub-group' of one of the Key Handicaps. Components of handicap are impairments, disorders, defects, etc. which can, according to their kind or degree in the individual, contribute to personal handicap.

The classification table provides a check-list of handicap enabling the clinician to record the final handicap status of his patients, in terms which are relevant to the individual's subsequent life-style, and which can be interpreted into presentation as 'difficulties' and 'special needs', which are the criteria of personal handicap. If a

\section{TABLE I}

The definitions of handicap

$A$ handicap is a long-term disadvantage which adversely affects an individual's capacity to achieve the personal and economic independence which is normal for his peers.

An extrinsic handicap is such a disadvantage arising from the individual's environment or circumstances (e.g. poverty, maternal deprivation, racial discrimination, residence in a depressed or disaster area).

An intrinsic handicap is such a disadvantage arising from the individual's own characteristics, from which he cannot be separated. 
TABLE II

Classification of the intrinsic handicaps (M. AGERHOLM, 1975)

Key handicaps

I Locomotor handicap (the locomotor handicapped)

2 Visual handicap (the visually handicapped)

3 Communication handicap (the communication handicap)

4 Visceral handicap (the viscerally handicapped)

5 Intellectual handicap (the intellectually handicapped)

6 Emotional handicap (the emotionally handicapped)

7 Invisible handicap (the invisibly handicapped)
Handicap components
A Impaired mobility in environment
B Impaired postural mobility (relation of parts of body to one another)
C Impaired manual dexterity
D Reduced exercise tolerance
A Total loss of sight
B Impaired (uncorrectable) visual acuity
C Impaired visual field
D Perceptual defect
A Impaired hearing
B Impaired talking
C Impaired reading
D Impaired writing
A Disorders of ingestion
B Disorders of excretion
C Artificial openings
D Dependence on life-saving machines
A Mental retardation (congenital)
B Mental retardation (acquired)
C Loss of learned skills
D Impaired learning ability
E Impaired memory
$F$ Impaired orientation in space or time
G Impaired consciousness
A Psychoses
B Neuroses
C Behaviour disorders
D Drug disorders (including alcoholism)
E Antisocial disorders
F Emotional immaturity

A Metabolic disorders requiring permanent therapy (e.g. diabetes, cystic fibrosis)

B Epilepsy, and other unpredictable losses of consciousness

C Special susceptibility to trauma (e.g. haemorrhagic disorders, bone fragility, susceptibility to pressure sores)

D Intermittent prostrating disorders (e.g. migraine, asthma, vertigo)

E Causalgia and other severe pain disorders

[Continued 
Key handicaps

8 Aversive handicap

(the aversively handicapped)

9 Senescence handicap

(the sensescence handicapped)
Handicap components

A Unsightly distortion or defect of part of body

B Unsightly skin disorders and scars

C Abnormal movements of body (athetosis, tics, grimacing, etc.)

D Abnormalities causing socially unacceptable smell, sight or sound

A Reduced plasticity of senescence

B Slowing of physical or mental function of senscence

C Reduced recuperative powers of senescence

'disabled' individual has no extra 'difficulties', no 'special needs' arising by virtue of his disablement and 'disabilities', then he is not handicapped only impaired, and can go on his way without special help from the handicap services.

\section{Part II (this paper)}

At this meeting I should like to report two further developments, since I975, in this area of identification of handicap, and its evaluation and recording in a language which crosses the disciplinary barriers between professions and also reaches the understanding of the layman-including that important person, the handicapped individual himself.

\section{Translatability of the classification and its nomenclature into different languages}

In the Part I paper I stipulated that, to be acceptable as a fundamental contribution to any field of work, a classification must be translatable into a wide range of 'tongues'. I expressed the hope that members of this multi-lingual Society might help me in this matter. And, sure enough, I can now express publicly my gratitude to Dr Michaelis who promptly offered his help, and his valued encouragement, too, for this enterprise of mine; and skilfully demonstrated that translation into German, at any rate, presented no linguistic problems. Since then, I have had the help of various colleagues, some contacted by Brian McGinnis at the DHSS on my behalf, and the following translations are now available: Finnish, French, German, Hebrew and Norwegian. I also have promise of an Italian, and the assurance that a Polish translation presents no linguistic problems. In fact, where linguistic problems do arise, they appear to be nonspecific, that is, characteristic of any translation from English into that language, rather than peculiar to the classification itself.

So the preliminary exercise suggests that the classification is translatable, meeting only the difficulties of translation generally.

\section{Application of the classification to recording the difficulties and needs of handicapped people}

In 1975 I reported that a Questionnaire form, based on the classification and its definitions, was about to be used in a pilot population Survey of handicapped 
people. This Questionnaire was intended as a tool, previously lacking, for the identification of handicapped people, in the context of provision of services, cash benefits, equipment, etc. to handicapped people. In this context, it is important not only to identify individual handicapped people, and so to count them; but to identify their kinds of handicap, and so the kinds of difficulty and the kinds of needs which they signify.

The Survey, a true pilot without statistical significance, was carried out in the square mile of the City of London, an atypical population of 6500 residents in approximately 2000 households. The Survey technique (volunteers, briefed interviewers, two-stage saturation, etc.) had already proved its virtues for the identification of handicapped people in the hands of a voluntary organisation, OUTSET. But there was dissatisfaction with the harvest of information obtained through the current Questionnaire design. Hence the pilot study of this Questionnaire.

The harvest on this occasion was happily most rewarding: it has been written up elsewhere (Agerholm et al., 1976). It has led on to use of the Questionnaire by invitation of statutory Authorities aware of their duties to the handicapped and of their inability hitherto to discover the basic information on which to build appropriate services and other provisions for carrying them out. A population of $\frac{3}{4}$ million, was followed by a population of $\mathrm{I} \frac{1}{4}$ million, currently begun and to last 2 years; and the best encouragement, perhaps, lies in the present approach from the neighbouring Authority to the $\frac{3}{4}$ million, for a similar Survey-using the OUTSET survey techniques and the Questionnaire, which have clearly together encouraged confidence in the value of these exercises.

This is not the place to discuss the principles of Questionnaire design, and why this particular design has proved such an effective tool for harvesting and interpreting information previously so difficult to harvest and interpret. It is, however, the place, to bring the Questionnaire, and its value in clinical as well as Survey work, briefly to your attention, as a useful tool which you may care to use in the rehabilitation and resettlement contexts of your work with spinal cordinjured patients. Briefly, the Questionnaire as used in Surveys, and in smaller numbers in casework by statutory and other agencies concerned with rehabilitation and resettlement of handicapped people, draws a handicap profile made up of three sections:

The Handicap Profile (Table III, a and b)

Section I records the individual's Personal Characteristics, relevant to the handicap context: his age, his code number, his/her sex, his disorder (e.g. lame, stiff hands, ageing, in a wheelchair, blind); his diagnosis (if available, e.g. multiple sclerosis, spinal cord damage, 'stroke'); and that important characteristic his 'kind of mobility', since mobility affects so many activities.

Section II records his Difficulties arising from the characteristics recorded in Section I, as answers to the Question, 'Do you have difficulty with . . . ?' related to ten selected Activity Headings (those Activities in which a certain level of proficiency is required if an individual is to achieve the personal autonomy expected of and by every individual human being). Each Activity has sub-headings, which can be ignored or included, according to whether difficulty is recognised in that activity generally.

Section III records the special Needs created by the difficulties. This Section, unlike Sections I and II which have general profile application, can be varied 
according to context. The one shown is the 'Health and Welfare' Section III. Section III's can be prepared for other contexts, e.g. Employment, Education (one for Tertiary Education is already on trial), for Residential Care, even for Travel, etc. according to the particular concern. The Health and Welfare version is probably the most complex and lengthy that we shall be asked to prepare.

\section{TABLE IIIa}

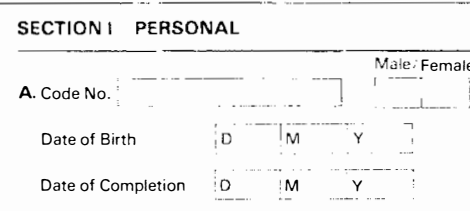

B. HANDICAP(S)

Please state kind of handicap (e.g. deafness, difficulty in walking, weak or stiff hands etc.)

and causes (if relevant) e.g. a diagnosis, like arthritis, and causes (if relevant) e.g. a diagnosis, like
multiple sclerosis, amputation etc.; or "ageing"

\section{MOBILITY CHARACTERISTICS}

Tick most appropriate group

Normally ambuian:

Ambulant but restricted

Ambutient with aid istick fraine exc

Ambulan: ony with fited appliance

Ambulant only wit

Walks bu: needs quicing or personal supoc:t

Waiks but cunnot stand sit unaided

Wheeichair user

Wheelchair bound

1 Bedpounit

12 Other

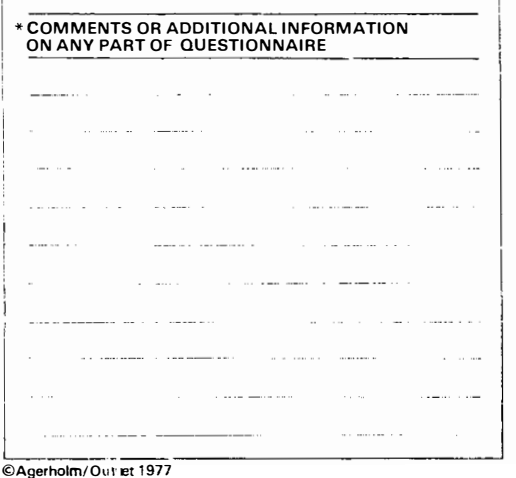

\section{SECTION II DIFFICULTIES EXPERIENCED}

DO YOU HAVE DIFFICULTY WITH (tick appropriate items!

A. GETTING OUT AND ABOUT

1 Gotting in and out of rouse

2 As pedestrian
3 In shops etc

On public transpor

5 Asselt-driver

As car passernger

As cyclis:

As wheelchair use

9 Because of severe ?t gue

With pariking

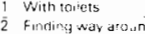

12 Finding way ato.un
13 Using guide dog

13. Using guide dog

15 Behaviour problens

16 Soeciar risks

B. MOVING AROUND ATHOME

Sars

Steps

Doors and passuctos

Doors and passager
Sereing things in waty

Sereing things ir war

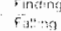

St: stand stance :

On of the

Lsing switches wencous at:

Reaching and pic xing things :

3 Otiey : s:ate:

\section{COMMUNICATION}

Heasing

Ialiking

Writ--

Antatioti

T:alkmg with stramiers

Talkilg with tarin

Cong telepnone

Goring ance cither sers

Get:ing he?

$\frac{\text { D. HOME CARE }}{3 \text { Light cienting }}$

3. Light cieaning

3. Thorough cleaning

Lignt ki:chen work

Bea making

6. Bea making

Minor repairs

Decordting and midimernance

Cleanerg wincow

Garden car

Shopping

E. FAMILY CAR

lother than of unhandicapped spouse)

Child care at home

Nursing of sick child or relative

Escorting farnity

Sunervising family activities

5 Communicating with ind tor family

6 Other istate;"

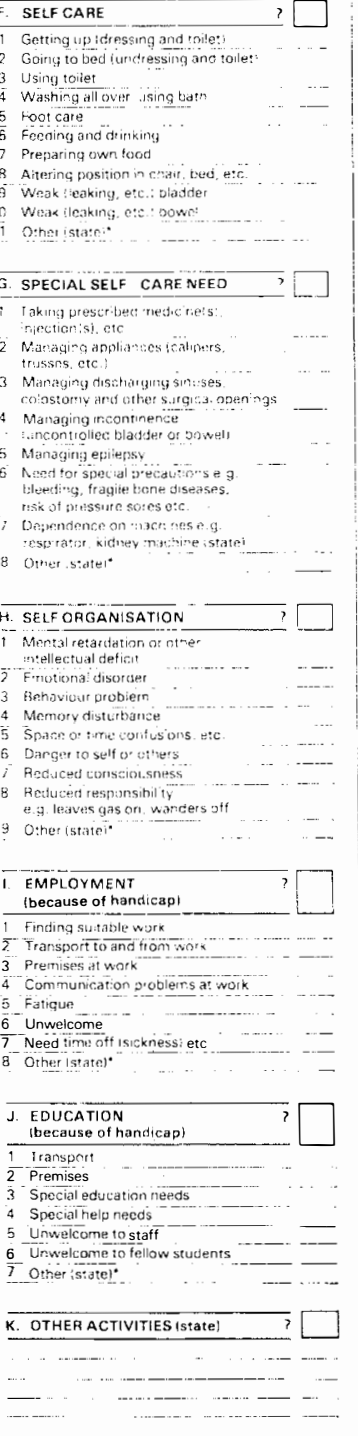




\section{TABLE IIIb}

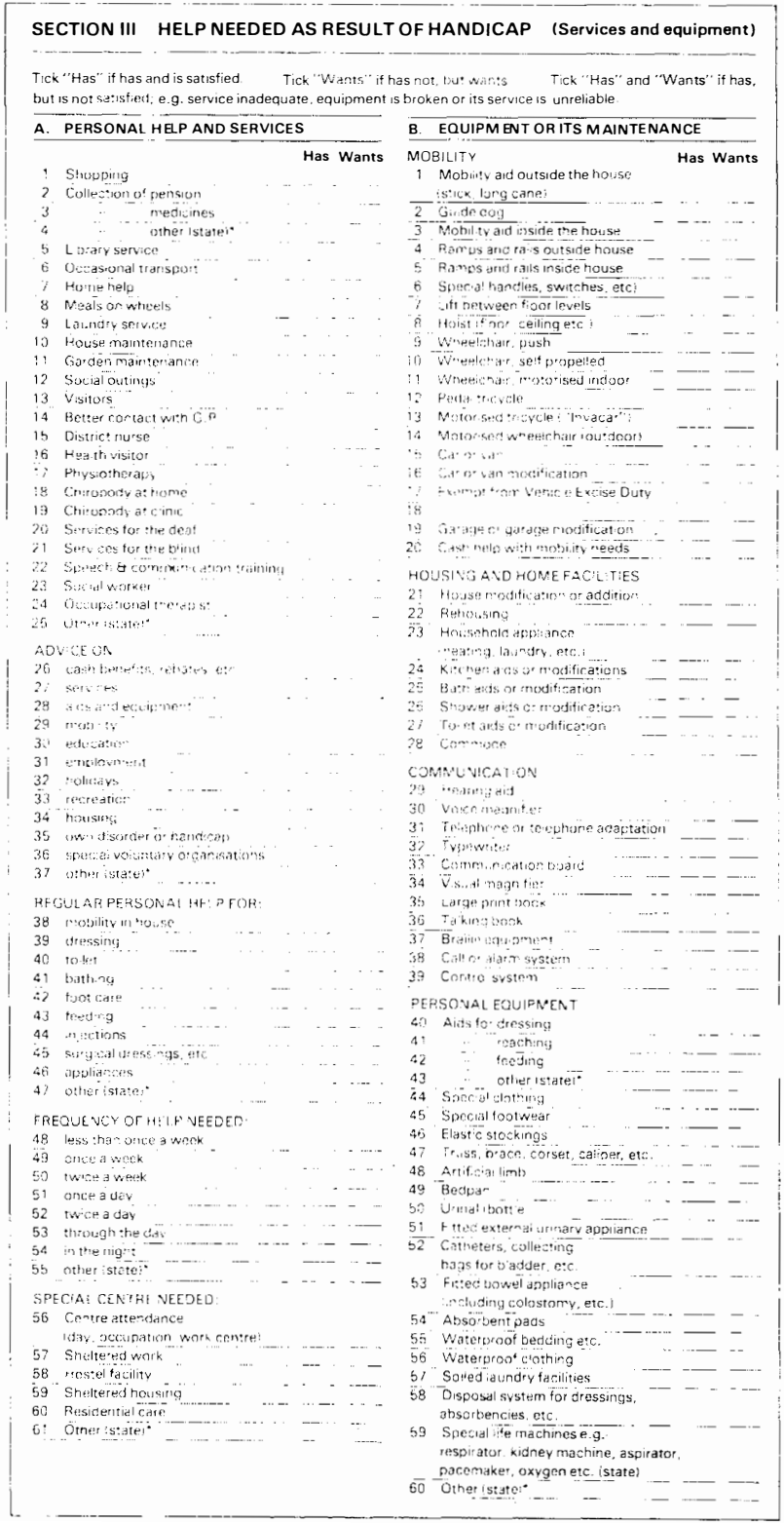

The final stage of the exercise was the design of an effective information storage and retrieval system. After some flirtation with computers and their print-outs, we have settled down happily with the Kalamazoo punch-card system, which accepts direct transfer of the information without 'interpretation'. It carries only the Code Number into the open statistical analysis 'exposures' of 
people's characteristics, difficulties and needs, and so helps to preserve confidentiality of personal information about individuals without losing the undoubted statistical value of some of the information obtained. In those areas where Surveys are carried out by this method, we shall have a good indication of how many people in the area are actually handicapped by such disorders as spinal cord damage, spina bifida, multiple sclerosis, mental handicap and visual handicap (to quote a few) as opposed to those carrying the diagnoses on hospital records, death certificates, etc., while at the same time, protecting people from idle identification by epidemiological scrutineers. Handicapped people need the protection of privacy as much as, or perhaps more than, the rest of us.

An innovation has been the 'self-carbonisation' of the Questionnaire, which allows every interviewee providing handicap information to keep his own copy, and so to know what has been recorded about himself. This prevents recording against the individual's wishes; it is, after all, he who is providing the information. Also it provides a useful document for him to hand to subsequent assessors in different contexts of handicap, and offers 'passport' information when he moves from one area to another, or between one activity and another, thus avoiding repeated assessment.

\section{Conclusion}

I express the hope that perhaps someone may be tempted to initiate in some other part of the world than the U.K. or in some other context than Surveys, a study to confirm or refute my original claim that handicap is the same 'round the world and down the centuries', or, as put by a colleague since, that handicap records can be 'culture-free'.

I believe that, using this questionnaire soundly based on the classification of handicap, we could build up a fascinating picture of handicapped people round the world, with the variations of patterns of handicap according to local prevalances of handicapping disorders, which could not only teach us a great deal about the needs of handicapped people in different parts of the world, but also teach us about the handicapping significance of the various handicapping disorders, and help us to distinguish the most urgent priorities of prevention of such disorders.

\section{SUMMARY}

Two developments are reported in the classification and nomenclature of handicap:

I. Translation of the classification and nomenclature into other tongues than English has presented no special linguistic problems and encourages confidence that the classification could have international use. Finnish, French, German, Hebrew and Norwegian translations are already available and others are in preparation.

2. The classification has been used as basis for construction of a Questionnaire form which elicits and records handicap information in three Sections: personal characteristics, difficulties and needs.

The completed Questionnaire presents a Handicap Profile which can be used in a variety of contexts, e.g. population survey, casework file, education and employment records, or as a Handicap Passport to identify eligibility for special provisions, e.g. services and cash benefits. The information can be transferred directly to computer or, better, to punched card (Kalamazoo) system for storage and retrieval, with built-in coding to conserve confidentiality of personal information.

The three sections of the Questionnaire are presented for international consideration. In the United Kingdom an initial pilot Survey, using OUTSET door-to-door interview techniques and the Questionnaire as tool, has led on to larger and larger population Surveys 
(up to $\mathrm{I} \frac{1}{2}$ million so far) with growing evidence that the techniques and tool together yield a bountiful harvest of directly relevant information on handicapped people and the handicapping disorders, including the important group of spinal cord lesions.

\section{RÉSUMÉ} clature:

Le communiqué concerne deux faits nouveaux à ce sujet de la classifications et nomen-

I. La traduction de la classification et nomenclature en d'autres langues que l'anglais n'a pas posé de problèmes spéciaux sur le plan linguistique et permet d'espérer que la classification serait susceptible d'être adoptée l'échelon international. On possède déjà la traduction en allemand, en finlandais, en français, en hébreu et en norvégien et la traduction en d'autres langues est en cours.

2. La classification a été employée comme base pour l'établissement d'un questionnaire qui permet d'obtenir et de noter l'information relative à l'handicap dans trois sections, à savoir: caractéristiques personnelles, difficultés et besoins.

Le questionnaire, une fois rempli, fournit un profil de l'handicap qu'il est possible d'utiliser dans toutes sortes de contextes comme, par exemple, le recensement, la fiche de cas individuel les dossiers concernant l'enseignement et l'emploi, ou comme 'Passeport d'Handicap' pour déterminer l'éligibilité pour certaines prestations spéciales en ce qui concerne, par exemple, les services fournis et les allocations. L'information peut être transmise directement à l'ordinateur ou, encore mieux, au système de cartes perforées (Kalamazoo) en vue de sa mémorisation et de sa recherche avec un code incorporé permettant de garantir la confidentialité des renseignements personnels.

Les trois sections du questionnaire sont présentées en vue de leur examen à l'échelon international. Au Royaume-Uni, une première enquête pilote baseé sur le'emploi des techniques d'interview de porte en porte et le questionnaire a abouti à des recensements démographiques de plus en plus importants (couvrant jusqu'a maintenant $1,500,000$ habitants) et ceci manifeste de plus en plus que c'est là un moyen permettant de récolter une grande quantité d'informations directement pertinentes concernant les personnes handicapées et les maladies à l'origine de l'handicap, y compris le groupe important des lésions de la modelle épinière.

\section{ZUSAMMENFASSUNG}

Bericht über zwei Entwicklungen auf diesem Arbeitsgebiet der Klassifikation und Nomenklatur:

I. Die Übersetzung der Klassifikation und Nomenklatur in andere Sprachen abgesehen von der englischen, hat keine besonderen Sprachprobleme mit sich gebracht und gibt Grund zur Annahme, dass die Klassifikation internationale Verwendung finden könnte. Finnische, französiche, deutsche, hebräische und norwegische übersetzungen stehen bereits zur Verfügung und andere sind im Vorbereitungsstadium.

2. Die Klassifikation wurde schon als Grundlage zur Erstellung eines Fragebogens verwendet für die Ermittlung und Erfassung von Behinderungs-Einzelheiten, welcherin drei Abscnitte gegliedert ist: persönliche Eigenheiten, Schwierigkeiten und Erfordernisse.

Der ausgefüllte Fragebogen gibt ein Behinderungsprofil das man auf verschiedenen Gebieten verwenden kann, z.B. bevölkerungsstatistische Untersuchungen, Einzelfallunterlagen, für Erziehungs- und Arbeitsnachweise, oder für die Ausstellung eines Invaliden-Ausweises der zu besonderen Leistungen berechtigt, z.B. Sonderdienste und finanzielle Unterstützung. Die Angaben können direkt in den Computer eingeführt werden oder noch besser in ein Lochkartensystem (Kalamazoo) zur Speicherung und Wiedergabe, mit eingebauten Schlüsselsystemen zur Wahrung der Vertraulichkeit der persönlichen Angaben.

Die drei Abschnitte des Fragebogens werden hiermit der internationalen Begutachtung unterbreitet. In Grossbritannien hat eine anfängliche Probeuntersuchung unter Anwendung des OUTSET Haus zu Haus Interview Systems mit dem Fragebogen als Untersuchungsmittel $\mathrm{zu}$ immer umfangreicheren bevölkerungsstatistischen Untersuchungen 
geführt, (bisher bis $\mathrm{I} \frac{1}{2}$ Millionen), mit zunehmenden Beweismaterial das daraufhindeutet, dass das System und Untersuchungsmittel zusammen einen reichlichen Ertrag von unmittelbar zweckdienlichen Informationen über Behinderte, Behinderungsleiden, einschliesslich der bedeutenden Gruppe von Wirbelsäulenverletzungen erschliessen.

\section{REFERENCES}

Agerholm, M. (1975a). Handicaps and the Handicapped: a nomenclature and classification of intrinsic handicaps. Roy. Soc. Hlth. F., p. 3.

Agerholm, M. (I975b). Identification and evaluation of long-term handicap. Med.-Legal Society, p. 3.

Agerholm, M., Blake, N. \& Cooke, K. R. (1976). Report of a Survey carried out in the City of London to identify its handicapped residents and their special needs and to evaluate a new Questionnaire designed to identify handicaps and handicapped people. OUTSET, 30 Craven Street, London WC2. 